\title{
Welcome Address: Chair of IPC
}

\author{
Sung Je Cho
}

I would like to express my utmost gratitude to His Excellency Lee Myung-bak, the President of the Republic of Korea for preparing a welcoming message for us despite his busy schedule.

Your Excellency Lee Ju Ho, Minister of Education, Science, and Technology, Professor Ingrid Daubechies, the President of IMU, Professor Bill Barton, the President of ICMI, Ladies and Gentlemen, distinguished guests and participants from all around the world, I would like to extend my warmest welcome to you all.

We, the Korean Mathematics Society and Korean Mathematics Education Society, are very proud to host the 12th International Congress on Mathematical Education. Our International Programme Committee has worked tirelessly through two face-to-face meetings and numerous internet discussions. It is needless to say that this Congress would not be possible without the dedicated and coordinated efforts of members of the various committees, presenters and participants. We thank all of you for making this a reality.

Mathematics has been at the heart of human culture, philosophy, technology and advancement since the dawn of civilization. We cannot think of our modern society apart from mathematics because mathematics influences every facet of our daily lives. Due to the far reaching effects of mathematics in our world, mathematics education may be one of the most efficient ways to influence betterment of mankind. For the week starting today, we are gathered here to nurture and cultivate the mathematics educational environment for our future generation so that they may become significant part of the solution and advancement of our society.

S.J. Cho $(\bowtie)$

International Programme Committee of ICME-12,

Seoul National University, Seoul, Republic of Korea

e-mail: sungjcho@snu.ac.kr

(C) The Author(s) 2015 
It is our sincere hope that this Congress would inspire wider and tighter mathematics education research network as well as inviting and stimulating mathematics classrooms all over the world.

Thank you,

Open Access This chapter is distributed under the terms of the Creative Commons Attribution Noncommercial License, which permits any noncommercial use, distribution, and reproduction in any medium, provided the original author(s) and source are credited. 